\title{
PRO SQL SERVER 2008 ANALYSIS SERVICES
}

\section{Iveta ŽOUŽELKOVÁ}

\begin{abstract}
The main aim of this paper is to introduce Pro SQL Server 2008 Analysis Services written by Philo Janus and Guy Fouché to potential readers. The publication is intended for young database professionals interested in data mining and OLAP analysis. It consists of 14 chapters and two appendixes and is richly illustrated by screenshots of the application software. It contains many useful examples and advices from practice.
\end{abstract}

Keywords: Microsoft SQL Server 2008, Analysis Services, OLAP Analysis, MDX, Business Intelligence, Decision Support, Database.

\section{PRO SQL SERVER 2008 ANALYTICKÉ SLUŽBY}

(JANUS, Philo; FOUCHÉ, Guy. Pro SQL Server 2008 Analysis Services. New York : Springer, 2010. 461 s. ISBN 978-1-4302-1995-8.)

Resumé: Cílem tohoto př́spěvku je seznámit čtenáře s knihou Pro SQL Server 2008 Analysis Services od autorì Philo Januse a Guye Fouchého. Publikace je primárně určena začínajicím databázovým odbornikům, zájemcům o OLAP a data miningové analýzy. Skládá se ze 14 kapitol a dvou príloh. Je bohatě ilustrovaná screenshoty aplikačního softwaru a obsahuje také mnoho užitečných př́kladů a rad z praxe.

Klíčová slova: Microsoft SQL Server 2008, Analytické služby, OLAP analýza, MDX, Business Intelligence, podpora rozhodování, databáze.

\section{1 Úvod}

Microsoft SQL Server 2008 patří $\mathrm{k}$ nejvyhledávanějším nástrojům nejen pro ukládání dat, ale také pro jejich analýzu. Analytické služby nabízené tímto serverem patři ke špičce v oboru databázových nástrojů. Kniha Pro SQL Server 2008 Analysis Services je zaměřena na tzv. OLAP analýzu (On-Line Analytical Processing), což je technika zpracování zpravidla obchodních dat. Její účel spočívá $\mathrm{v}$ získání podkladů pro podporu manažerského rozhodování.

\section{0 autorech}

Autoři recenzované knihy se řadí k předním odborníkům v oblasti Business Intelligence a podpory rozhodování.

Philo Janus $\mathrm{v}$ době vydání knihy působil na pozici „senior technology specialist" u společnosti Microsoft. Jeho práce se zaměřovala na implementaci produktu Microsoft Office Info Path do podnikových řešení (Microsoft Office Info Path je softwarový nástroj pro vytváření elektronických formulářů za účelem sběru dat). Díky těmto zkušenostem získal přehled o pořebách uživatelů i vývojářů zabývajících se vyhodnocováním dat.
Guy Fuché z Texasu se detailně zabývá systémy pro podporu rozhodování. Jeho poradenské zakázky tvoří široká paleta klientů z různých průmyslových odvětví včetně oblasti finančních služeb, vzdělávání, telekomunikací a zdravotního pojišstění. Bohaté zkušenosti se správou datového skladu zúročuje také $\mathrm{v}$ rámci své obsáhlé publikační činnosti.

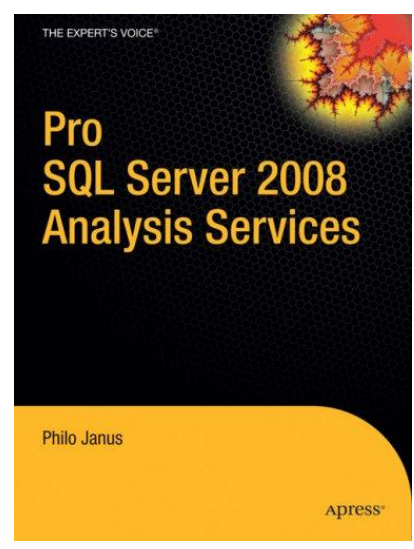

\section{3 Členění a obsah knihy}

Publikace je rozdělena do 14 kapitol a dvou př́loh. Čtenář je systematicky veden od vysvětlení pojmu OLAP až po pokročilý data 
mining. Každá kapitola je tvořena kratšími logicky členěnými oddíly, které jsou bohatě prokládány screenshoty aplikačního softwaru. Kapitoly současně obsahují cenné rady, poznámky a zkušenosti autorů z praxe. Kniha uvádí velké množství užitečných prríkladů za využití veřejně př́stupné databáze Adventure Works. Podrobný návod $\mathrm{k}$ jejímu stažení a naimportování na server naleznete $\mathrm{v}$ príloze (Apendix A).

První čtyři kapitoly jsou převážně informačního charakteru. Obsahují nezbytný teoretický základ, který je předpokladem pro úspěšné zvládnutí učebního textu. Úvod do OLAP analýzy (Introduction to OLAP) se snaží představit celý proces vyhodnocování dat a začlenit OLAP techniky do historických souvislostí. Součástí této části jsou také konkrétní ukázky praktického využití. Druhá kapitola je zaměřena na vysvětlení principu datových kostek, dimenzí a faktických dat (Cubes, Dimensions, and Measures). Jakmile čtenář zvládne základní terminologii, je seznámen s prostředím SQL Serveru 2008 a to konkrétně s SQL Server Business Intelligence Development Studiem, které se stane jedním z jeho pracovních nástrojů na další cestě za poznáním.

Kapitoly 5, 6 a 7 krok za krokem vysvětlují postup sestavení datových kostek - počínaje volbou datových zdrojů (Creating a Data Source View), vytváŕením dimenzí (Creating Dimensions) až po samotné nadefinování kostky (Building a Cube). Díky velmi podrobnému popisu postupu a vysvětlení dílčích nastavení není vytvoření datové kostky problém ani pro začátečníky. Jistá bazální znalost databázových systémů je zde však nezbytná.

Ve chvíli kdy máme kostku hotovou, můžeme si s ní začít „hrát“. Následující kapitola (Deploying and Processing) odkrývá pozadí prováděných postupů. Zmiňuje se o processingu vytvářených objektů. Tento proces by se dal chápat jako načtení faktických dat, provedení agregací a zadaných výpočtů nad těmito daty. Kapitola se také okrajově zabývá údržbou datových kostek a jejím plánováním.

Všechny předchozí sekce se více či méně zmiňovaly o vhodném jazyku pro dotazování se v rámci OLAP řešení - Multidimensional Expressions (MDX). Stejnojmenná 9. kapitola seznámí čtenáře $\mathrm{s}$ jeho základy a principem fungování. Jako všeobecná referenční příručka či učebnice tohoto jazyka se však označit nedá. Pro případného zájemce je pro hlubší studium MDX vhodnější podrobněji zpracovaná publikace.

Následující kapitoly jsou věnovány vlastnostem kostek (Cube Features), pokročilým technikám získávání informací z dat (Data Mining) a propojení SQL Serveru s programem Microsoft Excel (PowerPivot). Data miningové nástroje analytických služeb SQL Serveru mají v publikaci své nezastupitelné místo. Tato technologie zaujímá zásadní postavení především v oblasti Business Intelligence. Kniha popisuje algoritmy používané ke klasifikaci a predikci, což jsou jedny z elementárních úloh data miningu. Je zde popsána př́prava datového skladu a použití průvodce (Data Mining Model Designer) popř. MDX pro vytvoření analýzy tohoto typu. Další optimální studijní zdroje zabývající se tématem data miningu jsou uvedeny v príloze (Apendix $B$ ).

Závěr obsahuje několik stran zaměřených na administraci vytvořených datových objektů, sledování výkonnosti, zabezpečení, vizualizaci dat, user interface a na další uživatelsky nezbytné informace.

\section{Závěr}

Kniha je určena všem zájemcům o problematiku komplexního procesu OLAP analýzy v prostředí SQL Serveru 2008. Kapitoly jsou řazeny logicky a nezacházejí do detailů, což může být výraznou výhodou zvláště pro začátečníky. Mezi primární cíle autorů patří zejména objasnění základních principů, seznámení s prostředím a klíčovými pojmy. Velké množství př́kladů a podrobných obrazových návodů, které si může čtenář sám vyzkoušet, řadí tuto publikaci mezi výborné výukové materiály. Kniha vyšla $\mathrm{v}$ anglickém jazyce.

\section{Poděkování}

Článek vznikl za finanční podpory Interní grantové agentury Univerzity Tomáše Bati číslo IGA/49/FAI/10/D, SV30111049020.

\author{
Ing. Iveta Žouželková \\ Ústav počítačových a komunikačních systémů \\ Univerzita Tomáše Bati ve Zlíně \\ Fakulta aplikované informatiky \\ nám. T. G. Masaryka 5555, \\ 76001 Zlín, \\ Česká republika \\ telefon: +420 576035133 \\ E-mail: zouzelkova@fai.utb.cz, \\ Www pracoviště: www.fai.utb.cz
}

